\title{
NEKA OBILJEŽJA KLIME I KLIMATSKIH ELEMENATA NA PODRUČJU GRADA ZAGREBA
}

\section{SOME FEATURES OF CLIMATE AND CLIMATIC ELEMENTS IN THE AREA OF THE CITY OF ZAGREB}

\author{
Damir UGARKOVIĆ1* ${ }^{*}$ Matko MATIJEVIĆ2 ${ }^{\text {, Ivica TIKVIĆ }}$, Krešimir POPIĆ ${ }^{3}$
}

\begin{abstract}
SAŽETAK
Klimu kao prosječno stanje vremena određuju srednje vrijednosti, ali i kolebanja klimatskih elemenata. S obzirom na to da je klima najvažniji stanišni čimbenik, nužno ju je motriti, opisivati, analizirati i pratiti njezine promjene. Prikupljeni su podaci o vrijednostima temperature zraka $\left({ }^{\circ} \mathrm{C}\right)$, količine oborine $(\mathrm{mm})$ i relativne vlažnosti zraka (\%) za meteorološke postaje Grič, u središtu grada, i Maksimir, u suburbanom dijelu grada. Na osnovi promatranih i mjerenih klimatskih elemenata izračunati su različiti klimatski indeksi koji pobliže opisuju klimu grada Zagreba. Analiziran je i trend Palmerova indeksa oštrine suhoće (scPDSI). Temperatura zraka $\left({ }^{\circ} \mathrm{C}\right)$, količina oborine $(\mathrm{mm})$, kao i iznos potencijalne evapotranspiracije $(\mathrm{mm})$ imali su znatno više vrijednosti u središtu grada u odnosu na suburbani dio grada. Suburbani dio grada humidniji je u odnosu na središte grada. Trend Palmerova indeksa oštrine suhoće za travanj, srpanj i kolovoz upućuje na povećanje aridnosti na području Zagreba.
\end{abstract}

KLJUČNE RIJEČI: klima, Zagreb, urbani ekosustav

\section{UVOD}

\section{INTRODUCTION}

Klima je posredni ekološki čimbenik, a uz tlo je najvažniji stanišni čimbenik te ju je stoga nužno motriti, opisivati, kao i pratiti trendove pojedinih klimatskih elemenata i općenito sve vrste promjena klime kao ekološkog čimbenika. Klimatski čimbenici i klimatski elementi zajedno određuju klimu i vremenske prilike nekog područja (Šegota i Filipčić, 1996). Vrijeme i klima jednim dijelom utječu i na ugodnost života u gradovima, ljudsko zdravlje, gospodarstvo i poljoprivrednu proizvodnju. Vrijeme i klima imaju najveći utjecaj na rast bilja (Penzar i Penzar 2000).
Prema nekim autorima cijeli grad može se definirati kao jedan ekosustav, no također ga je moguće promatrati kao skup pojedinačnih ekosustava kao što su parkovi, jezera, urbane šume, obrađeno zemljište, gradska močvarna područja i potoci (Rebele 1994). Prema Marzluffu i dr. (2008) cijeli se ekosustav u gradu naziva urbani ekosustav koji uključuje abiotsku sferu, biotsku sferu i antroposferu. Klima i tlo u urbanim sredinama imaju drugačija obilježja u odnosu na šumske ili neke druge ekosustave. S obzirom na vrijednosti pojedinih klimatskih elemenata vrste šumskog drveća, koje od prirode dolaze na područje grada Zagreba, pronašle su tu svoju ekološku nišu. Vrste šumskog drveća u zagrebačkim park-šumama, parkovima i drvoredima su

\footnotetext{
Fakultet šumarstva i drvne tehnologije, Zavod za ekologiju i uzgajanje šuma, Svetošimunska 25, HR-10002 Zagreb, Croatia, izv. prof. dr. sc. Damir Ugarković, e-mail: dugarkovic@sumfak.unizg.hr, prof. dr. sc. Ivica Tikvić, e-mail: ivica.tikvic@zg.htnet.hr

${ }^{2}$ Frankopanska 45, 34000 Požega, Hrvatska, Matko Matijević, mag. ing. silv., e-mail: matkomatijevic532@gmail.com

${ }^{3}$ Hrvatske šume d. o. o. Zagreb, Uprava šuma Podružnica Vinkovci, Šumarija Lipovac, M. Gupca 5, HR-32246 Lipovac, Hrvatska,

Krešimir Popić, mag. ing. silv., e-mail: kresimir.popic@hrsume.hr

*korespondencija: dugarkovic@sumfak.unizg.hr, tel.: +38512352592
} 
prema zahtjevu za vodu uglavnom mezofiti do higrofiti, a prema kolebanjima topline, odnosno temperatura zraka, euritermne vrste. Prema Köppenovoj podjeli klima, klima na području grada Zagreba pripada klimatskom razredu C, umjereno tople vlažne klime, klimatski tip Cfb, umjereno topla vlažna klima s toplim ljetom čija je srednja, srpanjska temperatura zraka $<22,0^{\circ} \mathrm{C}$ (Šegota i Filipčić 2003).

Urbanizacija veoma utječe na mikroklimu i formiranje urbane klime (Zhang i dr. 2016). Karakteristike urbane klime mogu se sažeti na pet „otočnih” efekata, kao što su urbani toplinski otok (Rizwan i dr. 2008), urbani vlažni otok (Unger 1999), urbani sušni otok (Unkašević i dr. 2001), urbani zamagljeni otok (Cheng i Tsai 2000) i urbani kišni otok (Huff i Changnon 1973, Ji 2015). Građevine u središtu grada mijenjaju ne samo primanje i gubitak sunčeva zračenja nego i dugovalne izmjene i stanje protoka zraka. Povećanje zagrijavanja prostora i smanjenje površine koju pokriva vegetacija dovest će do promjena u akumuliranju topline, evapotranspiraciji i toplini koja se oslobađa izgaranjem goriva. Kao posljedica takvih promjena u središnjem dijelu gradu vjerojatno je da je srednja temperatura povećana, što je fenomen poznat kao urbani toplinski otok (Oke i dr. 2017).

Klima i klimatski elementi mijenjaju se tijekom vremena. O duljini vremenske skale ovisi i intenzitet promjena klimatskih elemenata. Na promjene klimatskih elemenata i pojava na području grada Zagreba te moguće posljedice upozoravaju Seletković i dr. (1993), Ivančan Picek i dr. (2017), Nimac i dr. (2018). Klimatske promjene količine oborine u Zagrebu za meteorološke postaje Grič i Maksimir istraživali su Gajić-Čapka (1992) te Filipčići i dr. (2013).

Prema Nimcu i dr. (2018) na prostoru jugoistočne Europe posebice će biti evidentne promjene klime i globalno zatopljenje, a urbana područja posebno su osjetljiva na klimatske promjene zbog urbanizacije i promjena u pokrovu.

S obzirom na to da se na području grada Zagreba nalazi i velik broj park-šuma s raznim vrstama šumskog drveća, a svaka vrsta ima svoju ekološku valenciju s obzirom na klimu, nužno je analizirati stresne uvjete za rast i razvoj šumskog drveća, a jedan od stresnih čimbenika svakako je i suša. Cilj je istraživanja prikazati i opisati klimu grada Zagreba za neke klimatske elemente te trendove samokalibriranog Palmerova indeksa oštrine suhoće (scPDSI).

\section{MATERIJALI I METODE RADA MATERIALS AND METHODS}

$S$ obzirom na to da klima predstavlja prosječan tijek vremena (Šegota i Filipčić 2003) te da se za opis klime nekog područja koristimo podacima dobivenim za dulje razdoblje, od 25 do 35 godina motrenja (Šegota i Filipčić 1996), iz Državnog hidrometeorološkog zavoda Republike Hrvatske (DHMZ) prikupljeni su podaci o vrijednostima klimatskih elemenata za meteorološke postaje Zagreb-Grič i Za-
greb-Maksimir. S predmetnih meteoroloških postaja prikupljeni su podaci o vrijednostima temperature zraka $\left({ }^{\circ} \mathrm{C}\right)$, količine oborine $(\mathrm{mm})$ te relativne vlažnosti zraka $(\%)$ za razdoblje od 1960. do 2004. godine (45 godina monitoringa). Meteorološka postaja Zagreb-Grič nalazi se na 157 metara nadmorske visine, a smještena je u centru grada Zagreba i predstavlja klimatske uvjete središta urbane sredine. Meteorološka postaja Zagreb-Maksimir nalazi se na 123 metra nadmorske visine, smještena je u istoimenoj gradskoj četvrti grada Zagreba te predstavlja klimatske uvjete u stambenom, suburbanom području Zagreba (Likso 2012).

Na osnovi srednjih mjesečnih vrijednosti temperature zraka određene su toplinske oznake klime $\left(\mathrm{t}^{\circ} \mathrm{C}\right.$, Gračanin i Ilijanić 1977). Humidnost klime određena je prema vrijednostima mjesečnih kišnih faktora (Gračanin 1950, Gračanin i Ilijanić 1977). Vrijednosti relativne vlažnosti zraka razvrstane su u sedam stupnjeva i napravljeni su grafički prikazi, odnosno tetragrami (Juričić 1942, Bertović 1975). Langov kišni faktor jedan je od najstarijih klimatskih indeksa, a predstavlja odnos srednje godišnje količine oborine $(\mathrm{mm})$ i srednje godišnje temperature zraka u ${ }^{\circ} \mathrm{C}$ (Lang 1915). Godišnji indeks aridnosti određen je prema Martonneu (1926), a indeks kontinentalnosti (k) prema metodi Conrad i Pollak (1950). Pluviotermički kvocijent $(\mathrm{Q})$ određen je prema Embergeru (1932). Potencijalna evapotranspiracija $(\mathrm{mm})$ izračunata je prema metodi Thornthwaitea (Šimunić 2013). Grafički prikaz odnosa temperature zraka i količine oborine te klimatski dijagrami napravljeni su prema Walteru (1955). Vegetacijsko razdoblje predstavlja period od 1. travnja do 30 . rujna. Podaci o samokalibriranom Palmerovu indeksu oštrine suhoće (scPDSI) prikupljeni su iz baze podataka KNMI Climate Explorer (https://climexp.knmi.nl/start.cgi). KNMI Climate Explorer mrežna je aplikacija za statističku analizu klimatskih podataka i dio je regionalnog klimatskog centra Svjetske meteorološke organizacije. Podatke smo prikupili za područje koordinata meteorološke postaje Zagreb-Grič. Srednje mjesečne vrijednosti temperatura zraka $\left({ }^{\circ} \mathrm{C}\right)$, količine oborine $(\mathrm{mm})$ i potencijalne evapotranspiracije $(\mathrm{mm})$ između meteoroloških postaja Grič i Maksimir uspoređene su Studentovim T-testom zavisnih uzoraka. Trendovi Palmerova indeksa oštrine suhoće (scPDSI) testirani su Mann-Kendall trend testom. Granica signifikantnosti za sve analize bila je $\mathrm{p}<0,05$. Svi podaci obrađeni su u programima KlimaSoft 2.0., Statistica 7.1. (StatSoft Inc. 2003) i Xlstat 2014.

\section{REZULTATI ISTRAŽIVANJA S RASPRAVOM RESEARCH RESULTS WITH DISCUSSION}

\section{Temperatura zraka i toplinska oznake klime Air temperature and heat codes of climate}

Temperatura zraka jedan je od glavnih meteoroloških, odnosno klimatskih elemenata. Osim srednjih vrijednosti temperature zraka, za obilježja klime važne su i njezine ek- 
Tablica 1. Vrijednosti temperature zraka $\left({ }^{\circ} \mathrm{C}\right)$ za meteorološke postaje u gradu Zagrebu od 1960. do 2004. godine Table 1 Air temperature values $\left({ }^{\circ} \mathrm{C}\right)$ for meteorological stations in the city of Zagreb from 1960 to 2004

\begin{tabular}{|c|c|c|c|c|c|c|}
\hline \multirow{2}{*}{$\begin{array}{l}\text { Meteorološka postaja } \\
\text { Met. station }\end{array}$} & \multicolumn{6}{|c|}{ Temperatura zraka $\left({ }^{\circ} \mathrm{C}\right)$ - Air temperature $\left({ }^{\circ} \mathrm{C}\right)$} \\
\hline & SG & SV & AMK & AMN & SK & AK \\
\hline Grič & 11,7 & 18,0 & 37,2 & $-17,2$ & 20,6 & 54,4 \\
\hline Maksimir & 10,6 & 17,0 & 38,5 & $-24,0$ & 20,7 & 62,5 \\
\hline
\end{tabular}

SG - srednja godišnja - average annual, SV - srednja vegetacijska - average vegetation, AMK - apsolutna maksimalna - absolute maximum, AMN - apsolutna minimalna - absolute minimum, SK - srednje kolebanje - medium fluctuation, AK - apsolutno kolebanje - absolute fluctuation

Tablica 2. Srednje mjesečne temperature zraka $\left({ }^{\circ} \mathrm{C}\right)$ i toplinske oznake klime za meteorološke postaje u gradu Zagrebu od 1960. do 2004. godine Table 2 Mean monthly air temperatures $\left({ }^{\circ} \mathrm{C}\right)$ and heat codes of the climate for meteorological stations in the city of Zagreb from 1960 to 2004

\begin{tabular}{|c|c|c|c|c|c|c|c|c|c|c|c|c|}
\hline \multirow{2}{*}{$\begin{array}{l}\text { Meteorološke postaje } \\
\text { Met. station }\end{array}$} & \multicolumn{12}{|c|}{ Mjeseci-Months } \\
\hline & I & II & III & IV & V & $\mathrm{VI}$ & VII & VIII & IX & $x$ & XI & XII \\
\hline \multirow{2}{*}{ Grič } & 1,0 & 3,4 & 7,6 & 12,0 & 16,6 & 19,8 & 21,6 & 21,2 & 17,0 & 12,0 & 6,6 & 2,1 \\
\hline & $\mathrm{h}$ & $\mathrm{h}$ & uhl & $\mathrm{t}$ & $\mathrm{t}$ & $\mathrm{t}$ & v & v & $\mathrm{T}$ & $\mathrm{t}$ & uhl & $\mathrm{h}$ \\
\hline \multirow{2}{*}{ Maksimir } & $-0,2$ & 2,1 & 6,3 & 10,8 & 15,6 & 18,9 & 20,5 & 20,0 & 15,9 & 10,8 & 5,5 & 1,0 \\
\hline & $n$ & $\mathrm{~h}$ & uhl & ut & $\mathrm{t}$ & $\mathrm{t}$ & v & v & $\mathrm{T}$ & ut & uhl & $\mathrm{h}$ \\
\hline
\end{tabular}

$\mathrm{v}$-vruća - hot $\left(>20^{\circ} \mathrm{C}\right), \mathrm{t}$ - topla - warm $\left(12-20^{\circ} \mathrm{C}\right)$, ut - umjereno topla - moderately warm $\left(8-12^{\circ} \mathrm{C}\right)$, uhl - umjereno hladna - moderately cold $\left(4-8^{\circ} \mathrm{C}\right), \mathrm{h}-\mathrm{hladna}$ $-\operatorname{cold}\left(0,5-4^{\circ} \mathrm{C}\right), \mathrm{n}-$ nivalna - nival $\left(<0,5^{\circ} \mathrm{C}\right)$

stremne vrijednosti, apsolutni maksimum i apsolutni minimum, kao i kolebanja temperature zraka.

Srednje vrijednosti temperature zraka za vegetacijsko razdoblje imaju znatno veće značenje za razvoj vegetacije nego srednje godišnje temperature zraka koje u pojedinim godinama u znatnoj mjeri ovise o temperaturi zraka zimi.

U Tablici 1. prikazane su vrijednosti temperatura zraka za meteorološke postaje Zagreb-Grič i Zagreb-Maksimir. Srednja godišnja temperatura zraka na meteorološkoj postaji Grič iznosila je $11,7^{\circ} \mathrm{C}$ sa standardnom devijacijom od $7,5^{\circ} \mathrm{C}$. Na području meteorološke postaje Maksimir, u suburbanom dijelu grada, srednja godišnja temperatura zraka iznosila je 10,6 ${ }^{\circ} \mathrm{C}$ sa standardnom devijacijom od $7,6^{\circ} \mathrm{C}$. Prema rezultatu Studentova T-testa zavisnih uzoraka, srednja godišnja temperatura zraka na meteorološkoj postaji Grič bila je statistički značajno viša od srednje godišnje temperature zraka na meteorološkoj postaji Maksimir ( $\mathrm{t}=33,96 ; \mathrm{p}=0,000)$. Srednja temperatura zraka u vegetacijskom razdoblju od travnja do rujna na Griču iznosila je $18,0^{\circ} \mathrm{C}$, a na području Maksimira $17,0^{\circ} \mathrm{C}$. Urbani toplinski otok najistaknutija je karakteristika urbane klime. Intenzitet urbanog toplinskog otoka proporcionalan je veličini populacije u gradu kao i veličini izgrađenog područja u gradu i prosječno iznosi oko $2^{\circ} \mathrm{C}$, a može se kretati i do $10^{\circ} \mathrm{C}$ (Chang i dr. 2007).

Apsolutne maksimalne i apsolutne minimalne temperature zraka pokazuju stvarne i ukupne toplinske razlike određenog područja. One su često limitirajući čimbenik za pridolazak, razvoj i opstanak neke vrste šumskog drveća (Seletković, 2001). Najveća apsolutna maksimalna temperatura zraka iznosila je $38,5^{\circ} \mathrm{C}$ na meteorološkoj postaji Maksmir, a na Griču $37,2{ }^{\circ} \mathrm{C}$. Apsolutna minimalna temperatura zraka na Griču iznosila je $-17,2^{\circ} \mathrm{C}$, a na području meteo- rološke postaje Maksimir $-24,0{ }^{\circ} \mathrm{C}$. Srednja kolebanja temperature zraka imala su približno jednake vrijednosti: 20,6 ${ }^{\circ} \mathrm{C}$ na Griču i $20,7^{\circ} \mathrm{C}$ na Maksimiru. Apsolutno kolebanje temperature zraka kretalo se od $54,4^{\circ} \mathrm{C}$ na meteorološkoj postaji Grič, do $62,5^{\circ} \mathrm{C}$ na meteorološkoj postaji Maksimir (Tablica 1). Velika razvedenost terena, a posebice čimbenici reljefa, kao što su nadmorska visina i nagib terena, često utječu na znatna odstupanja i u ekstremima temperature zraka. Međutim, to na području grada Zagreba nije slučaj, na znatna odstupanja apsolutne minimalne temperature zraka utjecala je urbanizacija, odnosno položaj predmetnih meteoroloških postaja, Grič u središtu grada ili središtu gradskog toplinskog otoka i postaje Maksimir koja je smještena u stambenom ili suburbanom dijelu grada.

U Tablici 2. prikazane su srednje mjesečne temperature zraka $\left({ }^{\circ} \mathrm{C}\right)$ i toplinske oznake klime za meteorološke postaje Grič i Maksimir.

Prema toplinskim oznakama, na meteorološkoj postaji Grič ukupno su bila tri hladna mjeseca, dva umjereno hladna, pet toplih i dva vruća mjeseca. Na meteorološkoj postaji Maksimir bio je jedan mjesec s nivalnom toplinskom oznakom, po dva hladna i umjereno hladna mjeseca, dva umjereno topla, tri topla mjeseca i dva vruća mjeseca. Srpanj i kolovoz uglavnom su vrući mjeseci. Samo je na meteorološkoj postaji Maksimir evidentiran mjesec sa srednjom temperaturom zraka nižom od $0,5^{\circ} \mathrm{C}$, a to je bio siječanj s nivalnom toplinskom oznakom (Tablica 2).

\section{Količine oborine i humidnost klime Precipitation and humid characteristics of climate}

Oborine su također glavni meteorološki ili klimatski element, važan za obilježja klime. Na meteorološkim posta- 
Tablica 3. Količina oborine $(\mathrm{mm})$ za meteorološke postaje u gradu Zagrebu od 1960. do 2004. godine

Table 3 Precipitation $(\mathrm{mm})$ for meteorological stations in the city of Zagreb from 1960 to 2004

\begin{tabular}{|c|c|c|c|}
\hline \multirow{3}{*}{$\begin{array}{l}\text { Meteorološka } \\
\text { postaja } \\
\text { Meteorological } \\
\text { station }\end{array}$} & \multicolumn{3}{|c|}{ Količina oborine $(\mathrm{mm})$ - Amount of precipitation $(\mathrm{mm}$} \\
\hline & $\begin{array}{l}\text { Srednja } \\
\text { godišnja }\end{array}$ & $\begin{array}{c}\text { Srednja } \\
\text { vegetacijska }\end{array}$ & $\begin{array}{l}\% \text { u veg. } \\
\text { razdoblju }\end{array}$ \\
\hline & $\begin{array}{c}\text { Average } \\
\text { annual }\end{array}$ & $\begin{array}{c}\text { Average } \\
\text { vegetation }\end{array}$ & $\%$ in veg. \\
\hline Grič & 881,3 & 501,1 & 56,9 \\
\hline Maksimir & 853,7 & 492,9 & 57,7 \\
\hline
\end{tabular}

jama Grič i Maksimir utvrđen je trend smanjenja količine oborine, međutim taj trend za meteorološku postaju Grič nije statistički značajan (Gajić-Čapka 1992), odnosno na postaji Maksimir trend smanjenja vrlo je blag (Filipčić i dr. 2013).

Srednja godišnja količina oborine na meteorološkoj postaji Grič iznosila je $881,3 \mathrm{~mm}$, a na meteorološkoj postaji Maksimir 853,7 mm (Tablica 3). Srednja mjesečna količina oborine na meteorološkoj postaji Grič iznosila je $73,4 \mathrm{~mm}$ sa standardnom devijacijom od 17,0 mm. U suburbanom dijelu grada, na meteorološkoj postaji Maksimir, srednja mjesečna količina oborine iznosila je 71,1 mm sa standardnom devijacijom od 18,4 mm.

Srednja mjesečna količina oborine bila je znatno viša u središtu grada na meteorološkoj postaji Grič $(t=3,13 ; \mathrm{p}=0,009)$ $\mathrm{u}$ odnosu na srednju mjesečnu količinu oborine u suburbanom dijelu grada na postaji Maksimir.

Srednja vegetacijska količina oborine iznosila je od 492,9 $\mathrm{mm}$ na meteorološkoj postaji Maksimir do 501,1 mm na postaji Grič. Postotak oborine u vegetacijskom razdoblju kretao se od 56,9 \% na postaji Grič do 57,7 \% na meteorološkoj postaji Maksimir (Tablica 3).

Iz godišnjeg hoda oborina može se zaključiti da je posrijedi kontinentalni oborinski režim, odnosno da veći dio količine oborine padne u toplijem dijelu godine. Maksimalne količine oborine padnu tijekom ljetnih mjeseci, a lipanj sa $95,6 \mathrm{~mm}$ na postaji Grič i kolovoz sa $89,3 \mathrm{~mm}$ oborine na postaji Maksimir su mjeseci s najvećom količinom oborine. Mjesec s najmanjom količinom oborine je veljača u iznosima od 42,9 mm na postaji Grič i 38,9 mm na postaji Maksimir (Tablica 4). S obzirom na raspodjelu oborina prema godišnjim dobima najveće količine oborine padnu ljeti (Grič 270,3 mm, Maksimir 267,2 mm), a drugi maksimum je jesen (Grič 254,5 mm, Maksimir 250,3 mm). Najmanje količine oborine padnu zimi (Grič 158,3 mm, Maksimir $144,7 \mathrm{~mm}$ ).

S obzirom na humidnost klime na meteorološkoj postaji Grič ukupno su bila dva perhumidna mjeseca, četiri humidna mjeseca, dva semihumidna mjeseca te četiri semiaridna mjeseca. U suburbanom dijelu grada, na postaji Mak-
Tablica 4. Srednje mjesečne količine oborine (mm), mjesečni kišni faktori i humidnost klime za meteorološke postaje u gradu Zagrebu od 1960. do 2004. godine

Table 4 Mean monthly precipitation $(\mathrm{mm})$, monthly rain factors and climate humidity for meteorological stations in the city of Zagreb from 1960 to 2004

\begin{tabular}{|c|c|c|c|c|c|c|}
\hline \multirow[b]{2}{*}{$\begin{array}{l}\text { Mjeseci } \\
\text { Months }\end{array}$} & \multicolumn{3}{|c|}{ Zagreb-Grič } & \multicolumn{3}{|c|}{ Zagreb-Maksimir } \\
\hline & 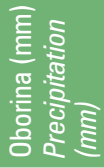 & 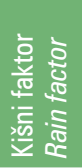 & 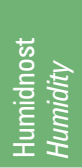 & 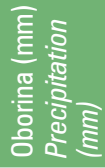 & 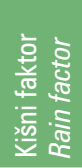 & 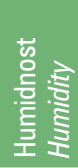 \\
\hline $\begin{array}{l}\text { Siječanj } \\
\text { January }\end{array}$ & 51,7 & 51,7 & ph & 46,0 & 230 & $\mathrm{ph}$ \\
\hline $\begin{array}{l}\text { Veljača } \\
\text { February }\end{array}$ & 42,9 & 12,6 & $\mathrm{~h}$ & 38,9 & 18,5 & ph \\
\hline $\begin{array}{l}\text { Ožujak } \\
\text { March }\end{array}$ & 55,5 & 7,3 & $\mathrm{~h}$ & 53,6 & 8,5 & $\mathrm{~h}$ \\
\hline $\begin{array}{l}\text { Travanj } \\
\text { April }\end{array}$ & 65,5 & 5,5 & sh & 64,4 & 6,0 & sh \\
\hline $\begin{array}{l}\text { Svibanj } \\
\text { May }\end{array}$ & 77,2 & 4,7 & sa & 73,5 & 4,7 & sa \\
\hline $\begin{array}{l}\text { Lipanj } \\
\text { June }\end{array}$ & 95,6 & 4,8 & sa & 96,0 & 5,1 & sh \\
\hline $\begin{array}{l}\text { Srpanj } \\
\text { July }\end{array}$ & 88,0 & 4,1 & sa & 81,9 & 4,0 & sa \\
\hline $\begin{array}{l}\text { Kolovoz } \\
\text { August }\end{array}$ & 86,7 & 4,1 & sa & 89,3 & 4,5 & sa \\
\hline $\begin{array}{l}\text { Rujan } \\
\text { September }\end{array}$ & 88,1 & 5,2 & sh & 87,8 & 5,5 & sh \\
\hline $\begin{array}{l}\text { Listopad } \\
\text { October }\end{array}$ & 79,6 & 6,6 & $\mathrm{~h}$ & 78,2 & 7,2 & $\mathrm{~h}$ \\
\hline $\begin{array}{l}\text { Studeni } \\
\text { November }\end{array}$ & 86,8 & 13,2 & $\mathrm{~h}$ & 84,3 & 15,3 & ph \\
\hline $\begin{array}{l}\text { Prosinac } \\
\text { December }\end{array}$ & 63,7 & 30,3 & ph & 59,8 & 59,8 & ph \\
\hline
\end{tabular}

ph - perhumidna - perhumid (> 13,3), h- humidna - humid $(6,7-13,3)$, sh - semihumidna - semihumide $(5,1-6,6)$, sa - semiardina - semiarid $(3,4-5,0)$, a - aridna - arid $(1,7-3,3)$, pa - peraridna - perarid $(<1,6)$

simir, humidnost klime blago je veća u odnosu na postaju u središtu grada. Na meteorološkoj postaji Maksimir bila su četiri perhumidna mjeseca, po dva humidna mjeseca, tri semihumidna mjeseca te dva semiaridna mjeseca (Tablica 4).

\section{Relativna vlažnost zraka \\ Relative air humidity}

Relativna vlažnost zraka jedan je od klimatskih elementa o kojem ovisi vlažnost stanica i tkiva biljnih organa. Postoji jaka i negativna korelacija između vrijednosti relativne vlažnosti zraka i temperature zraka. Povećanjem vrijednosti temperature zraka smanjuju se vrijednosti relativne vlažnosti zraka. Zbog tog odnosa najveće vrijednosti relativne vlažnosti zraka su u hladnijim mjesecima, a najmanje vrijednosti relativne vlažnosti zraka su u toplijim mjesecima. O vrijednostima temperature zraka i relativne vlažnosti zraka ovisi i transpiracija iz biljaka (Penzar i Penzar 2000).

Za navedene meteorološke postaje nema ekstremno vlažnog ni ekstremno suhog zraka, jer godišnji srednjak rela- 


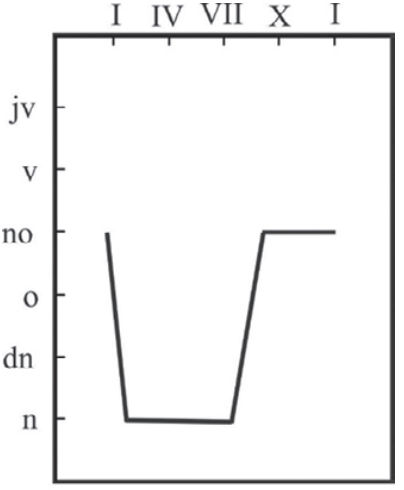

Zagreb - Grič $(70 \%)$

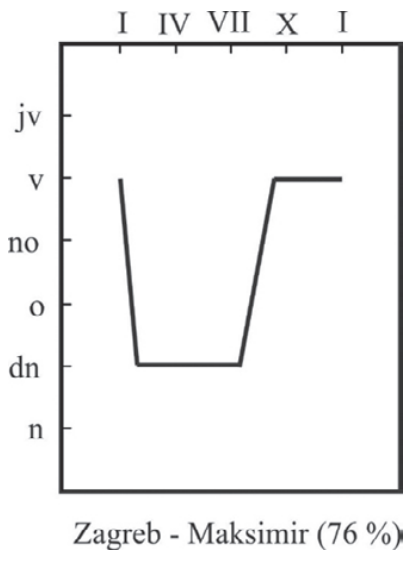

Slika 1. Tetragrami relativne vlažnosti zraka za meteorološke postaje Grič i Maksimir

Figure 1 Tetragrams of relative air humidity for meteorological stations Grič and Maksimir

jv - jako visoka - very high, $v$ - visoka - high, no - nadosrednja - transcedental, 0 - osrednja - medium, dn - dosta niska - quite low, n - niska - low

tivne vlage zraka nije nigdje veći od $85 \%$ i manji od $45 \%$. Promjene srednje relativne vlažnosti zraka u pojedinim sezonama prikazani se na tetragramima (Slika 1). Srednje vrijednosti kreću se od niske (45 - $64 \%)$ do nadosrednje (75 $-79 \%)$ za meteorološku postaju Grič te od dosta niske (65 - 69 \%) do visoke $(80-84 \%)$ za meteorološku postaju Maksimir. Srednja, godišnja, relativna vlažnost zraka na meteorološkoj postaji Grič bila je $70 \%$, a na meteorološkoj postaji Maksimir $76 \%$.

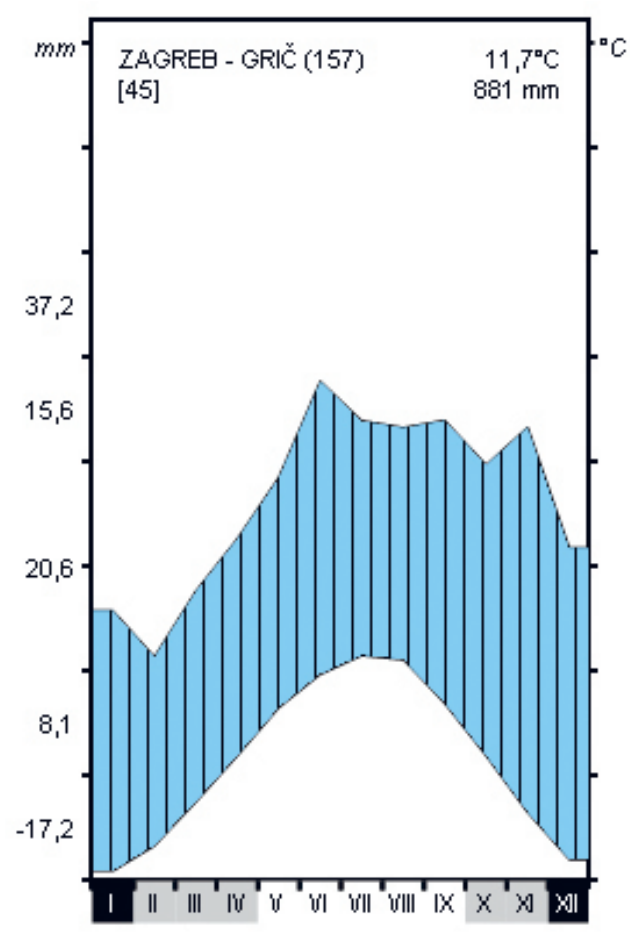

Slika 2. Klimatski dijagrami za meteorološke postaje u gradu Zagrebu Figure 2 Climate diagrams for meteorological stations in the city of Zagreb
U vegetacijskom razdoblju od travnja do rujna srednja, relativna vlažnost zraka kretala se od 60 do 71 \%. Najveća, srednja, relativna vlažnost zraka bila je u mjesecu prosincu u iznosu od $80 \%$. Najmanja, srednja, mjesečna, relativna vlažnost zraka bila je u mjesecu travnju u iznosu od $60 \%$ na meteorološkoj postaji Zagreb-Grič.

\section{Klimatski dijagrami i klimatski indeksi Climate diagrams and climate indices}

Jedan od načina analize klime i prikaza klime nekog područja su i klimatski dijagrami. Prema Walteru (1955) klimatski dijagrami predstavljaju grafički prikaz srednjih, mjesečnih temperatura zraka i srednjih, mjesečnih količina oborine određenog područja na temelju višegodišnjih meteoroloških motrenja. Na Slici 2. prikazani su klimatski dijagrami prema Walteru (1955) za meteorološke postaje Zagreb-Grič i Zagreb-Maksimir.

Prema klimatskim dijagramima za razdoblje od 45 godina (1960. - 2004.) tijekom cijele godine prisutno je vlažno ili humidno razdoblje, odnosno nema sušnog razdoblja. Najviše srednje mjesečne temperature zraka $\left({ }^{\circ} \mathrm{C}\right)$ na meteorološkim postajama su u srpnju. Srednja, srpanjska temperatura zraka na meteorološkoj postaji Zagreb-Grič iznosila je $21,6^{\circ} \mathrm{C}$, a na meteorološkoj postaji Zagreb-Maksimir 20,5 ${ }^{\circ} \mathrm{C}$. Vjerojatno zbog utjecaja grada i urbane sredine srednja, srpanjska temperatura zraka ima više vrijednosti na meteorološkoj postaji Grič u odnosu na postaju u Maksimiru.

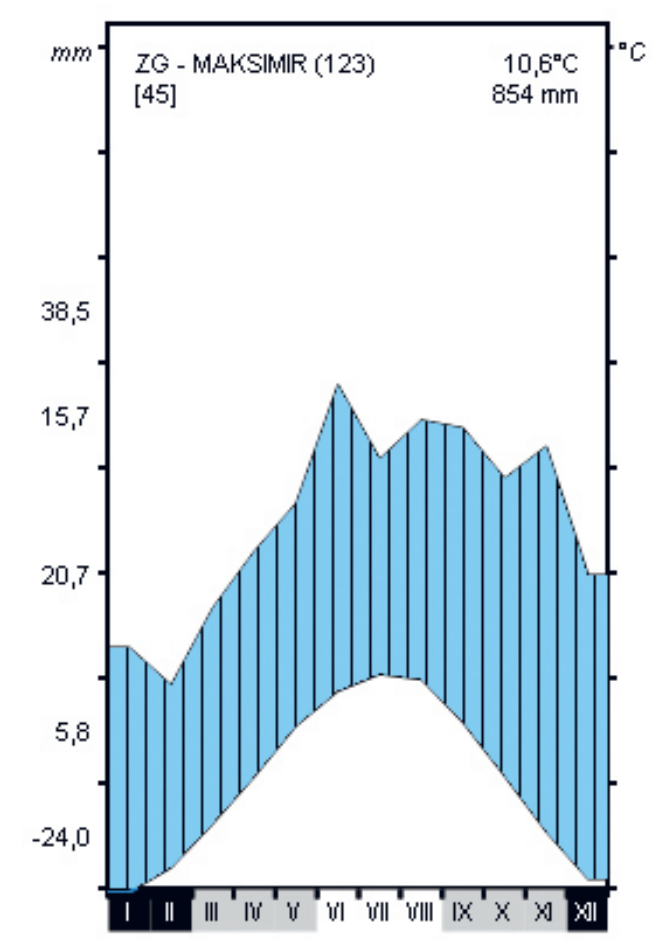


Tablica 5. Klimatski indeksi za meteorološke postaje u gradu Zagrebu od 1960. do 2004. godine

Table 5 Climate indices for meteorological stations in the city of Zagreb from 1960 to 2004

$\begin{array}{lcccc}\begin{array}{l}\text { Meteorološka } \\ \text { postaja } \\ \text { Meteorological } \\ \text { station }\end{array} & \text { LKf } & \text { IA } & K & 0 \\ \text { Grič } & 75,06 & 40,5 & 43,95 & 123,94 \\ & \begin{array}{c}\text { Semihumidna } \\ \text { Semihumide } \\ \text { Maksimir }\end{array} & \begin{array}{c}\text { Humidna } \\ \text { Humid }\end{array} & \begin{array}{c}\text { Kontinentalna } \\ \text { Continental }\end{array} & \begin{array}{c}\text { Humidna } \\ \text { Humid }\end{array} \\ & \begin{array}{c}\text { Semihumidna } \\ \text { Semihumide }\end{array} & \begin{array}{c}\text { Humidna } \\ \text { Humid }\end{array} & \begin{array}{c}\text { Kontinentalna } \\ \text { Continental }\end{array} & \begin{array}{c}\text { Humidna } \\ \text { Humid }\end{array}\end{array}$

IA - indeks aridnosti - Aridity index

LKf - Langov kišni faktor - Lang's rain factor

$\mathrm{k}$ - indeks (stupanj) kontinentalnosti - Index (degree) of continentality

0 - pluviotermički kvocijent - Pluviothermal quotient
Najveća količina oborine $(\mathrm{mm})$ na meteorološkim postajama Grič i Maksimir je u lipnju. Na Griču je zabilježeno 95,6 mm, a na Maksimiru 96,0 mm količine oborine u lipnju. Iz klimatskih dijagrama vidimo da je najveća količina oborine u toplijem dijelu godine, odnosno u vegetacijskom razdoblju od travnja do rujna, što je obilježje kontinentalnog oborinskog režima.

Mogućnost pojave mraza na meteorološkoj postaji ZagrebGrič je od siječnja do travnja te od listopada do prosinca. Mraz se na meteorološkoj postaji na području Maksimira može pojaviti od siječnja do svibnja te od rujna do prosinca.

Pomoću klimatskih indeksa pobliže opisujemo klimu i klimatska obilježja nekog područja. Vrijednosti nekih klimatskih indeksa za meteorološke postaje Grič i Maksimir nalaze se u Tablici 5. Prema vrijednostima Langova kišnog

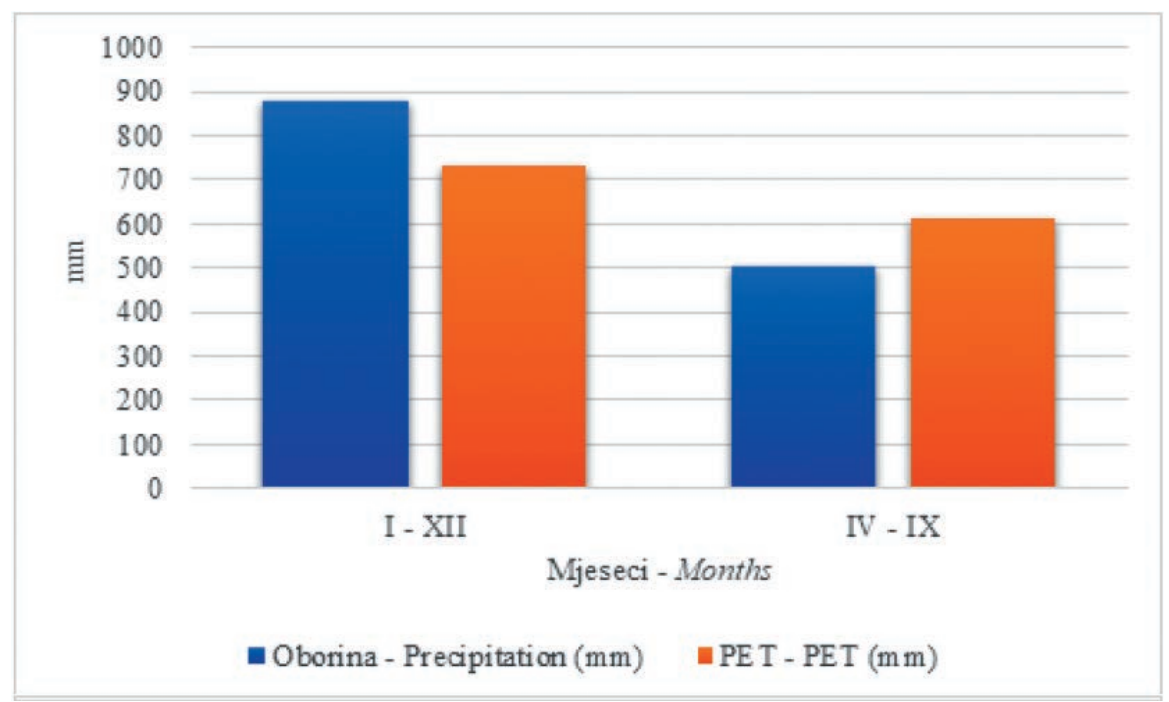

Slika 3. Odnos godišnjih i vegetacijskih količina oborine i potencijalne evapotranspiracije (PET) za meteorološku postaju Zagreb-Grič Figure 3 Relationship between annual and vegetation precipitation and potential evapotranspiration (PET) for meteorological station Zagreb-Grič

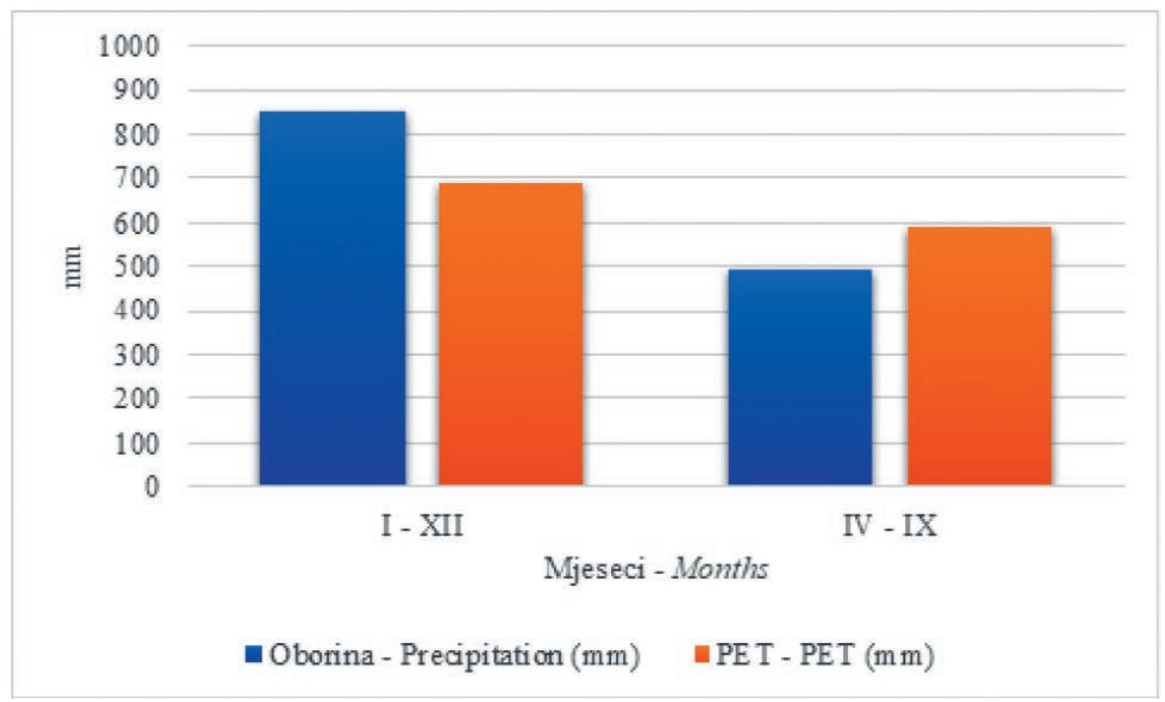

Slika 4. Odnos godišnjih i vegetacijskih količina oborine i potencijalne evapotranspiracije (PET) za meteorološku postaju Zagreb-Maksimir Figure 4 Relationship between annual and vegetation precipitation and potential evapotranspiration (PET) for the meteorological station Zagreb-Maksimir 
faktora, klima na području Zagreba je semihumidna. S obzirom na indeks aridnosti i vrijednosti pluviotermičkog kvocijenta klima na području Zagreba je humidna. Indeks ili stupanj kontinentalnosti klime pokazuje nam da Zagreb ima kontinentalnu klimu (Tablica 5).

$\mathrm{Na}$ Slici 3. prikazan je odnos godišnih i vegetacijskih količina oborine i potencijalne evapotranspiracije (PET) za meteorološku postaju Zagreb-Grič. Na godišnjoj razini veća je količina oborine u odnosu na iznos potencijalne evapotranspiracije za $151,5 \mathrm{~mm}$. Tijekom vegetacijskog razdoblja iznos količine oborine bio je manji od iznosa potencijalne evapotranspiracije za 112,9 mm.

Ako detaljnije analiziramo odnos količine oborine i potencijalne evapotranspiracije na mjesečnoj razini, tijekom siječnja, veljače, ožujka, travnja, rujna, listopada, studenog i prosinca evidentirana je veća količina oborine u odnosu na iznos potencijalne evapotranspiracije. U svibnju, lipnju, srpnju i kolovozu evidentirana je manja količina oborine u odnosu na iznos potencijalne evapotranspiracije. Najveći suficit vode u iznosu od $+64,2 \mathrm{~mm}$ bio je u studenom, a najmanji suficit u iznosu od $+8,5 \mathrm{~mm}$ u rujnu. Najveći deficit vode bio je u srpnju u iznosu od $-49,5 \mathrm{~mm}$, a najmanji u svibnju u iznosu od $-18,5 \mathrm{~mm}$.

$\mathrm{Na}$ Slici 4. prikazan je odnos godišnjih i vegetacijskih količina oborine i potencijalne evapotranspiracije za meteorološku postaju Zagreb-Maksimir. Na godišnjoj razini količina oborine veća je od iznosa potencijalne evapotranspiracije za $165,0 \mathrm{~mm}$. Tijekom vegetacijskog razdoblja iznos oborine manji je od iznosa potencijalne evapotranspiracije za $95,6 \mathrm{~mm}$.

U siječnju, veljači, ožujku, travnju, rujnu, listopadu, studenom i prosincu veća je količina oborine od iznosa potencijalne evapotranspiracije, odnosno bio je suficit vode na postaji Maksimir. Najveći suficit vode u iznosu od $+63,8$ $\mathrm{mm}$ bio je u studenom, a najmanji u iznosu od $+11,5 \mathrm{~mm}$ bio je u rujnu. Tijekom svibnja, lipnja, srpnja i kolovoza postojao je deficit vode na postaji Maksimir. Najveći deficit u iznosu od $-49,5 \mathrm{~mm}$ bio je u kolovozu, a najmanji u iznosu od -19,0 mm u svibnju.

Srednja mjesečna potencijalna evapotranspiracija na postaji Grič iznosila je $60,81 \mathrm{~mm}$ sa standardnom devijacijom od 49,63 mm. Na meteorološkoj postaji Maksimir srednja mjesečna potencijalna evapotranspiracija iznosila je $57,39 \mathrm{~mm}$ sa standardnom devijacijom od 48,54 mm. Iznos srednje mjesečne potencijalne evapotranspiracije bio je statistički značajno veći na meteorološkoj postaji Grič ( $(\mathrm{t}=8,84 ; \mathrm{p}=0,000)$.

Zagreb je po veličini srednjoeuropski grad smješten uz rijeku Savu i na južnim padinama Medvednice, zbog čega je i njegova klima raznolika (Nimac 2018). To potvrđuju i rezultati ovog istraživanja usporedbe glavnih klimatskih elemenata i indeksa za meteorološke stanice Grič u urbanom, središnjem dijelu grada i Maksimir u suburbanom dijelu grada.

\section{Suša kao klimatološki ekstrem Drought as a climatological extreme}

Jedno je od obilježja klimatskih promjena povećanje vrijednosti temperature zraka i potencijalne evapotranspiracije (Ugarković i dr. 2019) te učestala pojava sušnih godina sa sve duljim sušnim razdobljima (Mikac i dr. 2018). Utjecaji promjene temperature zraka i količine oborine mogu biti odlučujući čimbenik za smanjenje vitalnosti stabala (Ugarković i Pleša 2017). Uz naglo smanjenje količine oborine istodobno se povećava temperatura zraka, što fiziološki oslabljuje stabla i uzrokuje stresna stanja kod šumskog drveća. Klimatske promjene rezultirat će šumskim poremećajima, kao što su patogeni, insekti i požari, te će sve više utjecati na zemljopisnu distribuciju, rast i održivost vrsta šumskog drveća na svijetu (Sturrock i dr. 2011). Uz temperaturu zraka koja ovisi o oblačnosti i insolaciji, oborina ima najveće značenje za razvoj vegetacije, jer je ona glavni izvor vlage u tlu. Manjak oborine uz pojavu visoke temperature zraka slabi otpornu snagu šumskog drveća, jer se pojačanom transpiracijom troši velika količina vode. Dulja sušna razdoblja utječu na isušenje tla i pogoršanje fizioloških procesa u stablima. Povećanje srednje, godišnje i vegetacijske temperature zraka te pojava klimatskih ekscesa, važnih za današnju promjenu klime, mogu izazvati stresna stanja kod vrsta uske ekološke valencije. To se poglavito odnosi na neposredne ekološke čimbenike: toplinu i vodu. Drveće u urbanim sredinama izloženo je toplinskom stresu, niskoj vlažnosti zraka i suši tla. Povećanje temperatura zraka i sve češća toplinska i sušna razdoblja pojačat će razinu stresa urbanih stabala (Gillner i dr. 2014), a ekstremne suše mogu uzrokovati mortalitet stabala u urbanim sredinama (Savi i dr. 2015).

Suša je razdoblje izrazitog nedostatka vode u tlu i vodotocima, koje nastaje zbog izostanka oborina i pojave iznadprosječno visokih temperatura zraka. Više je oblika

Tablica 6. Deskriptivna statistika Palmerova indeksa oštrine suhoće (scPDSI) na području grada Zagreba (1901. - 2017.)

Table 6 Descriptive statistics of the Palmer dryness index (scPDSI) in the area of the city of Zagreb (1901 - 2017)

\begin{tabular}{lccc}
$\begin{array}{l}\text { Mjeseci } \\
\text { Months }\end{array}$ & $\begin{array}{c}\text { Prosjek } \pm \text { std.dev. } \\
\text { Mean } \pm \text { std.dev. }\end{array}$ & $\begin{array}{c}\text { scPDSI } \\
\text { Minimum } \\
\text { Minimum }\end{array}$ & $\begin{array}{c}\text { Maksimum } \\
\text { Maximum }\end{array}$ \\
$\begin{array}{l}\text { Travanj } \\
\text { April } \\
\text { Svibanj } \\
\text { May }\end{array}$ & $0,37 \pm 1,90$ & $-5,84$ & 4,28 \\
$\begin{array}{l}\text { Lipanj } \\
\text { June }\end{array}$ & $0,31 \pm 1,82$ & $-5,61$ & 3,90 \\
$\begin{array}{l}\text { Srpanj } \\
\text { July } \\
\text { Kolovoz }\end{array}$ & $0,29 \pm 1,86$ & $-5,21$ & 3,68 \\
$\begin{array}{l}\text { August } \\
\text { Rujan } \\
\text { September }\end{array}$ & $0,32 \pm 2,14$ & $-6,26$ & 5,19 \\
\hline
\end{tabular}


Tablica 7. Trendovi Palmerova indeksa oštrine suhoće (scPDSI) za mjesece u vegetacijskom razdoblju na području grada Zagreba (1901. - 2017.)

Table 7 Trends of the Palmer dryness index (scPDSI) for months in the vegetation period in the area of the city of Zagreb (1901 - 2017)

\begin{tabular}{|c|c|c|c|c|}
\hline $\begin{array}{l}\text { Mjeseci } \\
\text { Months }\end{array}$ & $\begin{array}{l}\text { Jednadžba trenda } \\
\text { Trend equation }\end{array}$ & $\begin{array}{c}\text { Kendall's } \\
\text { tau }\end{array}$ & $\begin{array}{l}\text { Sen's } \\
\text { slope }\end{array}$ & $\begin{array}{c}p \text {-vrijednost } \\
p \text {-value }\end{array}$ \\
\hline $\begin{array}{l}\text { Travanj } \\
\text { April }\end{array}$ & $Y=-0,0132 x+1,1536$ & $-0,145$ & $-0,012$ & 0,021 \\
\hline $\begin{array}{l}\text { Svibanj } \\
\text { May }\end{array}$ & $Y=-0,01 x+0,9096$ & $-0,114$ & $-0,008$ & 0,071 \\
\hline $\begin{array}{l}\text { Lipanj } \\
\text { June }\end{array}$ & $Y=-0,0111 x+0,9519$ & $-0,115$ & $-0,009$ & 0,068 \\
\hline $\begin{array}{l}\text { Srpanj } \\
\text { July }\end{array}$ & $Y=-0,0147 x+1,1605$ & $-0,152$ & $-0,014$ & 0,016 \\
\hline $\begin{array}{l}\text { Kolovoz } \\
\text { August }\end{array}$ & $Y=-0,014 x+1,1477$ & $-0,127$ & $-0,013$ & 0,043 \\
\hline $\begin{array}{l}\text { Rujan } \\
\text { September }\end{array}$ & $Y=-0,0106 x+0,9887$ & $-0,097$ & $-0,01$ & 0,125 \\
\hline
\end{tabular}

suše, kao što su agronomska suša, meteorološka suša i hidrološka suša (Jug i dr. 2011). Postoji nekoliko metoda, odnosno načina, kako odrediti sušu, a jedna je od njih metoda koju je 1965. godine razvio Palmer (Palmer 1965). Palmerov indeks oštrine suhoće (PDSI) mjeri odstupanje opskrbe vlagom. Taj je indeks meteorološki indeks suše (Karl i Knight 1985). Za izračun Palmerova indeksa oštrine suhoće potrebno je poznavati podatke o količini oborine i temperature te udio vode $\mathrm{u}$ tlu. Palmerov indeks oštrine suhoće upotrebljava se za monitoring suše i sušnih razdoblja (Willeke i dr. 1994).

U Tablici 6. nalaze se deskriptivni statistički pokazatelji za kalibrirani Palmerov indeks oštrine suhoće za područje grada Zagreba. Najveći minimum u vrijednosti od -6,26 (ekstremno suho) zabilježen je u kolovozu 2012. godine. Najveća maksimalna vrijednost u iznosu od 5,58 (ekstremno vlažno) evidentirana je u rujnu 1937. godine. Prosječne vrijednosti scPDSI kretale su se od 0,28 do 0,37 (blizu normale).

Trendovi Palmerova indeksa oštrine suhoće za mjesece $u$ vegetacijskom razdoblju prikazani su u Tablici 7. Prema rezultatima Mann-Kendall trend testa, postoji padajući trend scPDSI za travanj (Kendall's tau $=-0,145$, Sen's slope $=-0,012, \mathrm{p}=0,021)$.

Za svibanj ne postoji statistički značajan trend scPDSI (Kendall's tau $=-0,114$, Sen's slope $=-0,008, \mathrm{p}=0,071)$. Trend scPDSI za lipanj je padajući, ali nije statistički značajan (Kendall's tau $=-0,115$, Sen's slope $=-0,009, p=0,068$ ). Za srpanj trend scPDSI bio je padajući, odnosno negativnog trenda. Prema rezultatima Mann-Kendall trend testa, taj trend bio je statistički značajan (Kendall's tau $=-0,152$, Sen's slope $=-0,014, p=0,016$ ). Također postojao je padajući trend scPDSI u kolovozu (Kendall's tau $=-0,127$, Sen's slope $=-0,013, p=0,043)$. Prema rezultatima Mann-Ken- dall trend testa, za rujan trend nije bio statistički značajan (Kendall's tau $=-0,097$, Sen's slope $=-0,01, p=0,125$ ).

$S$ obzirom na porast srednje godišnje temperature zraka (Ivančan-Picek i dr. 2017, Nimac i dr. 2018) te smanjenje količine oborine (Gajić-Čapka 1992, Filipčić i dr. 2013), pretpostavlja se da će se povećati broj semiaridnih mjeseci, a smanjiti broj perhumidnih i humidnih mjeseci u gradu. Sve to ide u prilog povećanju aridnosti na području grada, na što nas upućuje i trend Palmerova indeksa oštrine suhoće (scPDSI). Očekuje se i veći broj dana sa sušom, što će u urbanim uvjetima gdje je prisutno veće površinsko otjecanje vode stvarati otežavajuće uvjete za šumsko drveće.

\section{ZAKLJUČCI}

\section{CONCLUSIONS}

Iako je grad Zagreb prema veličini srednje velik grad, a zračna udaljenost meteoroloških postaja Grič i Maksimir manja je od pet kilometara, vrijednosti analiziranih klimatskih elemenata u središtu grada razlikuju se u odnosu na vrijednosti u suburbanom dijelu grada. U središtu grada Zagreba znatno su više vrijednosti srednje godišnje temperature zraka u odnosu na suburbani dio grada. Količine oborine kretale su se od $854 \mathrm{~mm}$ u suburbanom dijelu grada do $881 \mathrm{~mm}$ u središtu grada. S obzirom na humidnost klime i mjesečne kišne faktore suburbani dio grada humidniji je u odnosu na središte grada. Iznos potencijalne evapotranspiracije bio je veći u središtu grada u odnosu na suburbani dio grada. Srednja godišnja relativna vlažnost zraka veća je u suburbanom dijelu grada u odnosu na središte grada. Apsolutno kolebanje temperature zraka bilo je veće u suburbanom dijelu grada $(62,5$ ${ }^{\circ} \mathrm{C}$ ) u odnosu na središte grada gdje je iznosilo $54,4{ }^{\circ} \mathrm{C}$. Na godišnjoj razini iznosi količine oborine veće su od iznosa potencijalne evapotranspiracije. Međutim, tijekom mjeseci u vegetacijskom razdoblju, a što je važno za šumske vrste drveća i ostalu vegetaciju u gradu, iznos količine oborine bio je manji od iznosa potencijalne evapotranspiracije. Prema vrijednostima Langova kišnog faktora, klima na području grada Zagreba je semihumidna. S obzirom na indeks aridnosti i pluviotermički kvocijent, klima je humidna. Trendovi Palmerova indeksa oštrine suhoće $u$ proljeće (travanj) te $\mathrm{u}$ dva najtoplija mjeseca $\mathrm{u}$ godini (srpanj, kolovoz) imaju značajan trend upućujući na povećanje aridnosti na području grada Zagreba. U kontekstu klimatskih promjena nužno je nastaviti monitoring i analizu urbane klime, a isto tako povećati broj postaja s motrenjem klime.

S obzirom na nastavak klimatskih promjena i povećanje vrijednosti temperature zraka te češće pojave sušnih razdoblja pojačat će se razina stresa kod drveća u urbanim sredinama. 


\section{LITERATURA}

\section{REFERENCES}

- Bertović, S., 1975: Acta Biologica VII/2, Prilog poznavanju odnosa klime i vegetacije u Hrvatskoj, Jugoslavenska akademija znanosti i umjetnosti, 215 str., Zagreb.

- Chang, C. R., M. H. Li, S. D. Chang, 2007: A preliminary study on the local cool-island intensity of Taipei city parks. Landscape and Urban Planing 80: 386-395.

- Cheng, M. T., Y. I. Tsai, 2000: Characterization of visibility and atmospheric aerosol sin urban, suburban and remote areas. Sci. Total Environ. 263: 101-114.

- Conrad, V., L. W. Polak, 1950: Methods in Climatology, Harvard University, str. 212, Cambridge.

- Emberger, L., 1932: Sur une formule climatique et ses applications en botanique, La Météorologie 423.

- Filipčić, A., D. Orešić, M. Maradin, 2013: Promjene količine padalina u Hrvatskoj od sredine 20. stoljeća do danas. Geoadria 18 (1): 29-39.

- Gajić-Čapka, M., 1992: Stationarity, Trend and Periodicity of Precipitation at the Zagreb-Grič Observatory from 1862 to 1990. Hrvatski meteorološki časopis 27: 1-10.

- Gillner, S., A. Bräuning, A. Roloff, 2014: Dendrochronological analysis of urban trees: climatic response and impact of drought on frequently used tree species. Trees 28: 1079-1093.

- Gračanin, M., 1950: Mjesečni kišni faktori i njihovo značenje u pedološkim istraživanjima, Poljoprivredna znanstvena smotra 12,51 .

- Gračanin, M., Lj. Ilijanić, 1977: Uvod u ekologiju bilja, Školska knjiga, 289 str., Zagreb.

- Huff, F. A., S. A. Changnon, 1973: Precipitation modification by major urban areas. Bulletion of the American Meteorological Society 54: 1220-1220.

- Ivančan-Picek, B., I. Guettler, K. Zaninović, L. Cvitan, A. Bajić, L. Srnec, K. Cindrić Kalin, M. Perčec Tadić, 2017: Projekcije klimatskih promjena na području grada Zagreba. Deveta regionalna konferencija Sigurnost gradova SIGG 2017. Opatija, Hrvatska, 16-17. 03. 2017. Sažeci sa skupova.

- Ji, W., 2015: Understanding urban wetland dynamics: Crossscale detection and analysis of remote sensing. Int J Remote Sens 36. 1763-1788.

- Jug, D., B. Stipešević, I. Jug, M. Mesić, 2011: Agroklimatološki pojmovnik, Poljoprivredni fakultet u Osijeku, 118 str., Osijek.

- Juričić, H., 1942: Vlaga u zraku, Zemljopis Hrvatske, I, Zagreb.

- Karl, T. R. i R. W. Knight, 1985: Atlas of Monthly Palmer Hydrological Drought Indices (1931-1983) for the Contiguous United States. Historical Climatology Series 3-7, National Climatic Data Center, Asheville, NC.

- KNMI Climate Explorer (https://climexp.knmi.nl/start.cgi).

- Lang, R., 1915: Versuch einer exakten Klassifikation der Böden in klimatischer und geologischer Hinsicht, Internationale Mitteilungen für Bodenkunde 5, 313.

- Likso, T., 2012: Procjena brzine vjetra u suburbanom prizemnom sloju atmosfere. Doktorska disertacija, Prirodoslovnomatematički fakultet Sveučilišta u Zagrebu, str. 98.

- Martonne, E. de, 1926: Une nouvelle fonction climatique: 1' indice d' aridité, La Météorologie, str. 449.
- Marzluff, J. M., E. Shulenberger, W. Endlicher, M. Alberti, G. Bradley, C. Ryan, U. Simon, C. ZumBrunnen, 2008: Urban Ecology. An International Perspective on the interaction Between Human and Nature. Springer Science and Business Media, New York.

- Mikac, S., A. Žmegač, D. Trlin, V. Paulić, M. Oršanić, I. Anić, 2018: Drought-induced shift in tree response to climate in floodplain forests of Southeastern Europe, Scientific Reports 8: 1. -12.

- Nimac, I., I. Herceg Bulić, M. Perčec Tadić, K. Zaninović, 2018: Urban climate of Zagreb (Croatia) - its caracteristics and changes. EMS Annual Meeting Abstracts Vol. 15, EMS2018563-1.

- Oke, T.R., G. Mills, A. Christen, J.A. Voogt, 2017: Urban Climates. Cambridge University Press, 520. str., Cambridge.

- Palmer, W. C., 1965. Meteorological Drought. Research Paper No.45, U.S. Depertment of Commerce Weather Bureau, Washington, D.C.

- Penzar, I., B. Penzar, 2000: Agrometeorologija, Školska knjiga, 222 str., Zagreb.

- Rebele, F., 1994: Urban Ecology and Special Features of Urban Ecosystems. Glob. Ecol. Biogeogr. 4: 173-187.

- Rizwan, A. M., L. Y. C. Dennis, C. Liu, 2008: A review on the generation, determination and mitigation of urban heat island. J Environ Sci 20: 120-128.

- Savi, T., S. Bertuzzi, S. Branca, M. Tretiach, A. Nardini, 2015: Drought-induced xylem cavitation and hydraulic deterioration: risk factors for urban trees under climate change? New Phytol 205: 1106-1116.

- Seletković, Z., M. Ivkov, I. Tikvić, 1993: Prilog istraživanjima klimatskih elemenata i pojava u zagrebačkoj regiji tijekom ovog stoljeća. Glasnik za šumske pokuse, posebno izdanje 4: 25-34.

- Seletković, Z., 2001: Klima i hidrološke prilike u dinarskim jelovim šumama u Hrvatskoj, U: B. Prpić (ur.), Obična jela ( $A b$ ies alba Mill.) u Hrvatskoj, Akademija šumarskih znanosti, 133.-141., Zagreb

- StatSoft, Inc. 2003. STATISTICA for Windows. Tulsa: StatSoft, Inc.

- Sturrock, R. N., S. J. Frankel, A. V. Brown, P. E. Hennon, J. T. Kliejunas, K. J. Lewis, J. J. Worrall, A. J. Woods, 2011: Climate change and forest diseases. Plant Pathol. 60: 133-149.

- Šegota, T., A. Filipčić, 1996: Klimatologija za geografe, Školska knjiga, 471 str., Zagreb.

- Šegota, T., A. Filipčić, 2003: Köppenova podjela klima i hrvatsko nazivlje, Geoadria 8/1: 17. - 37.

- Šimunić, I., 2013: Uređenje voda, Hrvatska sveučilišna naklada, str. 260, Zagreb.

- Ugarković, D., K. Pleša, 2017: Usporedba odumiranja stabala hrasta lužnjaka i poljskog jasena u odnosu na ekološku konstituciju vrsta. Sumar list 5-6: 227-236.

- Ugarković, D., Ž. Španjol, I. Tikvić, D. Kapučija, I. Plišo Vusić, 2019: Microclimate differences in the degradation stages of Holm oak (Quercus ilex L.) forests. Sumar list 9-10: 391-402.

- Unger, J., 1999: Urban-rural air humidity differences in Szeged, Hungary. Int J of Climatol 19: 1509-1515.

- Unkašević, M., O. Jovanović, T. Popović, 2001: Urban-suburban / rural vapour pressure and relative humidity differences at fixed hours over the area of Belgrade city. Theor. Appl. Climatol. 68: 67-73. 
- Zhang, W., Y. Zhu, J. Jiang, 2016: Effect of the Urbanization of Wetlands on Microclimate: A Case Study of Xixi Wetland Hangzhou, China. Sustainability 8, 885: 1-13.

- Walter, H., 1955: Die Klimadiagramme als Mittel zur Beurteilung der Klimaverhältnisse für ökologische, vegetation- skundliche und landwirtschaftliche Zwecke, Ber. Dtsch. Bot. Ges., LVIII, 8.

- Willeke, G., J. R. M. Hosking, J. R. Wallis i N. B. Guttman, 1994: The National Drought Atlas. Institute for Water Resources report 94-NDS-4, U.S. Army Crops of Engineers.

\section{SUMIMARY}

Climate as an average weather condition is determined by average values, but also by fluctuations of climatic elements. Given that climate is the most important habitat factor, it is necessary to observe, describe and monitor its changes. Data on air temperature $\left({ }^{\circ} \mathrm{C}\right)$, precipitation $(\mathrm{mm})$ and relative humidity (\%) values were collected for meteorological stations Grič, in the city centre, and Maksimir, in the suburban part of the city. Based on the observed and measured climatic elements, various climate indices were calculated that describe the climate of the city of Zagreb in more detail. An analysis of the trend of the Palmer dryness index (scPDSI) was made. Air temperature $\left({ }^{\circ} \mathrm{C}\right)$, precipitation amount $(\mathrm{mm})$ as well as the amount of potential evapotranspiration $(\mathrm{mm})$ had significantly higher values in the city centre compared to the suburban part of the city. The suburban part of the city is more humid compared to the city centre. The trend of the Palmer dryness sharpness index for April, July and August indicates an increase in aridity in the Zagreb area.

KEY WORDS: climate, Zagreb, urban ecosystem 